CASSOWARY volume 5 (1) Januari 2022: 69 - 80

ISSN : 2614-8900

E-ISSN : 2622-6545

Program Pascasarjana Universitas Papua, https://pasca.unipa.ac.id

\title{
Karakter morfologi dan nutrisi genotipe talas mapia di Distrik Supiori Utara dan Timur Kabupaten Supiori Provinsi Papua
}

\author{
Benti Purba $^{1)}$, Saraswati Prabawardani ${ }^{2) *}$, Wasgito Purnomo ${ }^{2)}$, Yohanis Amos \\ Mustamu ${ }^{2)}$ \\ ${ }^{1)}$ Program Studi S2 Ilmu Pertanian Program Pascasarjana Universitas Papua, Jalan \\ Gunung Salju, Amban, Manokwari, Papua Barat, 98314, Indonesia \\ ${ }^{2)}$ Program Studi Agroteknologi, Fakultas Pertanian Universitas Papua, Jalan Gunung \\ Salju, Amban, Manokwari, Papua Barat, 98314, Indonesia \\ *Email: s.prabawardani@unipa.ac.id
}

Disubmit: 11 November 2021, direvisi: 31 Januari 2022, diterima: 10 April 2021 Doi: https://doi.org/10.30862/casssowary.cs.v5.i1.120

\begin{abstract}
This study aimed to identify morphological characters and analyze the nutrition of the Mapia taro genotype and other taro genotypes in Kpudori and Warbor villages in North Supiori district and Wakre and Wafor villages in East Supiori district. The research was conducted in June - August 2020 using a descriptive method with survey techniques. Chemical analysis of tubers was carried out at the Agroclimatology Laboratory, Faculty of Agriculture, University of Papua and the Laboratory of Chemistry and Food Technology, Research Institute for Nuts and Tubers, Malang. In this method, taro samples were taken from a population of taro plants in a predetermined village in each of the North and East Supiori districts. The sampling method for morphological characterization was carried out randomly on 3 taro plants per village. Observations on plant morphological characteristics (above gound plant part) were carried out on taro plants aged approximately 90-150 days after planting (DAT). While the morphological characterization of tubers was carried out at harvest. The standardized qualitative and quantitative data were processed using the SPSS program with cluster analysis to determine the level of similarity between the genotypes of each sample of each taro. Cluster analysis produced a dendogram which was used to assess the level of similarity of the taro genotypes from the data obtained. The results showed that the highest association coefficient values were found in the KDR-TP and KDR-IU genotypes of 11.044. This shows that the two genotypes have a low level of similarity compared to other taro genotypes. While the lowest coefficient value was found in the WKR-TP and WFR-TP genotypes with a coefficient value of 4.064, indicating that the WKR-TP and WFR-TP accessions had a high degree of similarity. The results of the chemical analysis of tubers varied in 6 genotypes of taro. The highest water content was WBR-TP genotype (87.88\%), ash content (4.59\%) in WFR-TP genotype, starch content (67.24\%) in WKRIP genotype, sugar content (11 0.01\%) in KFR-IU, amylose content $(22.91 \%)$ in WBR$\mathrm{TP}$, fat content $(0.64 \%)$ in KDR-IU, protein content $(8.81 \%)$ in WFR-TP.
\end{abstract}

Keywords: Taro, Morphology, Nutrition, Cluster Analysis, Supiori 


\section{PENDAHULUAN}

Tanaman talas (Colocasia esculenta) tumbuh di daerah tropis lembab, merupakan kelompok tanaman herbaceous yang bersifat perennial, dan memiliki nilai nutrisi dan ekonomi penting pada umbinya. Umbinya mengandung karbohidrat dan kalori tinggi sehingga dimanfaatkan sebagai salah satu pangan pokok oleh masyarakat di wilayah kepulauan Pasifik termasuk Papua, Afrika, Asia, India Barat, dan Amerika Selatan. Di Papua New Guinea (PNG) dan wilayah kepulauan Pasifik, talas pada mulanya merupakan tanaman pokok sumber karbohidrat penting, namun karena serangan hama dan penyakit (faktor biotik) dan faktor abiotik, produksinya menurun dan tergantikan oleh tanaman ubijalar yang lebih adaptif (Singh and Okpul, 2000; Yalu et al., 2009). Tanaman talas merupakan jenis tanaman pangan fungsional, karena selain bernu-trisi umbinya mengandung senyawa yang berkhasiat untuk kesehatan seperti Kalium (K) yang berguna untuk menjaga kerja dan kesehatan jantung serta tekanan darah, Mangan (Mn) memperlancar metabolisme protein dan lemak di dalam tubuh (Goncalves et al., 2013).

Keterikatan masyarakat pada talas juga terlihat dalam budaya pada beberapa daerah di Indonesia, Oceania dan Asia Tenggara. Talas adalah komoditas berharga di PNG untuk kegiatan sosial budaya seperti pembayaran kompensasi, upacara harga pengantin dan pesta (Singh dan Okpul, 2000). Bagi masya-rakat Papua, talas merupakan salah satu tanaman ubi-ubian yang penting setelah ubijalar. Sebagai contoh, sebanyak $64 \%$ masyarakat di distrik Ayamura, menjadi-kan talas sebagai makanan pokok. Talas juga dikonsumsi oleh lebih dari $50 \%$ rumah tangga di Jayawijaya dan dalam konsumsinya menempati urutan kedua
$(20,1 \%)$ setelah ubi jalar $(48,09 \%)$ (Purwantini dan Saliem 2011). Tanaman ini dapat hidup di dataran rendah sampai ketinggian $2.700 \mathrm{mdpl}$ dengan suhu seki$\operatorname{tar} 21-27^{\circ} \mathrm{C}$ (Minantyorini dan Hanarida 2002).

Seiring dengan meningkatnya jumlah penduduk di Indonesia, semakin tinggi pula tuntutan kebutuhan pangan. Beras yang selama ini menjadi ketergantungan penduduk Indonesia, masih diimpor dari luar, sehingga perlu adanya penganekaragaman pangan yang bersumber dari pangan lokal. Talas merupakan salah satu pangan lokal yang berpotensi sebagai sumber pangan alternatif dan perlu dikembangkan untuk mendukung ketahanan pangan.

Talas merupakan salah satu sumberdaya genetik tanaman yang tersebar di tanah Papua, diantaranya wilayah Supiori. Supiori merupakan salah satu Kabupaten yang berada di Provinsi Papua yang memiliki penyebaran tanaman talas di pekarangan maupun di hutan rawa. Salah satu jenis tanaman talas yang karakter morfologinya berbeda dari jenis talas lainnya karena ukuran tanamannya besar dan tinggi tampaknya endemik di daerah Mapia, Kabupaten Supiori, sehingga disebut talas Mapia atau Burak dalam bahasa lokal setempat. Selain jenis talas lainnya, talas Mapia merupakan salah satu tanaman pangan lokal rakyat Supiori, namun populasinya relative terbatas.

Informasi keragaman genetik maupun morfologi tanaman talas perlu diketahui sebagai dasar pertimbangan dalam penyusunan strategi konservasi, pemuliaan, pengelolaan, dan pemanfaatan sumber daya genetik serta mewujudkan diversifikasi pangan lokal secara berkelanjutan. Sehubungan dengan hal tersebut maka sangat perlu untuk melakukan karakterisasi morfologi dan menganalisis nutrisi umbi talas tersebut. Penelitian ini bertujuan untuk mengiden- 
tifikasi karakter morfologi dan menganalisis nutrisi umbi talas Mapia dan genotipe talas lainnya di wilayah Supiori.

\section{METODE}

Penelitian dilaksanakan di Kampung Kpudori dan Warbor (Distrik Supiori Utara) dan Kampung Wakre dan Wafor (Distrik Supiori Timur), Kabupaten Supiori, sedangkan analisis kimia umbi dilakukan di Laboratorium Agroklimatologi Fakultas Pertanian Universitas Papua, Manokwari dan Laboratorium Kimia dan Teknologi Pangan Balai Penelitian Tanaman Aneka Kacang dan Umbi Malang. Penelitian berlangsung pada bulan Juni sampai Agustus 2021.

Penelitian menggunakan metode deskriptif dengan tehnik survei. Dalam metode ini sampel kampung ditentukan secara sengaja dari masing-masing distrik Supiori Utara dan Timur. Jumlah responden $15 \mathrm{KK}$ per distrik. Penentuan lokasi dilakukan berdasarkan survei dan wawancara dengan masyarakat dan tokoh masyarakat setempat yang telah dilakukan pada bulan Januari 2020.

Metode pengambilan sampel untuk karakterisasi morfologi dilakukan secara acak pada 3 tanaman talas per kampung. Pengamatan terhadap karakteristik morfologi tanaman dilakukan pada tanaman yang berumur kurang lebih 90-150 hari setelah tanam (HST). Sementara pengamatan karakteristik morfologi umbi dilakukan pada saat panen. Variabel yang diamati meliputi (1) Karakteristik morfologi, berupa tipe tanaman, karakter daun, cormus (umbi), dan (2) Analisis kimia umbi meliputi kadar air, kadar abu, pati, gula, amilosa, protein, lemak.

Data dianalisis secara tabulasi dan ditampilkan dalam bentuk gambar dan tabel. Karakter morfologi digunakan untuk melakukan analisis pengelompokkan untuk melihat tingkat kemiripan antar genotipe talas. Data kualitatif dan kuantitatif yang telah terstandarisasi diolah menggunakan program SPSS dengan analisis cluster untuk mengetahui tingkat kemiripan antar genotipe talas.

\section{HASIL DAN PEMBAHASAN}

\section{Genotipe Talas}

Hasil penelitian menunjukkan adanya 6 genotipe talas, terdiri dari 4 genotipe yang umum disebut talas Mapia oleh masyarakat lokal distrik Supiori dan 2 genotipe talas lainnya yang disebut $n$ Ifen Putih dan Ifen Ungu (Tabel 1).

\section{Karakter Morfologi}

\section{Tipe Tanaman}

Pada Tabel 2, rentang tanaman talas terpanjang terdapat pada genotipe WBR-TP $(151,6 \mathrm{~cm})$ dan rentang terpendek terdapat pada genotipe KDR-TP $(92,3 \mathrm{~cm})$.

Tabel 1. Genotipe Talas di Distrik Supiori

\begin{tabular}{llll}
\hline Distrik & Kampung & \multicolumn{1}{c}{ Genotipe Talas } & \multicolumn{1}{c}{ Kode } \\
\hline Supiori & Wakre & (1) Talas Mapia & (1) WKR-TP \\
Timur & & (2) Talas Ifen Putih (Bete Putih) & (2) WKR-IP \\
& Wafor & (1) Talas Mapia & (1) WFR-TP \\
Supiori & Warbor & (1) Talas Mapia & (1) WFR-TP \\
Utara & Kpudori & (1) Talas Mapia & (1) KDR-TP \\
& & (2) Talas Ifen Ungu (Bete Ungu) & (2) KDR-IU \\
\hline
\end{tabular}


Tabel 2. Tipe Tanaman Talas di Kabupaten Supiori

\begin{tabular}{llllll}
\hline \multirow{2}{*}{$\begin{array}{l}\text { Genotipe } \\
\text { Talas }\end{array}$} & $\begin{array}{l}\text { Rentang } \\
\text { tanaman } \\
(\mathrm{cm})\end{array}$ & $\begin{array}{l}\text { Tinggi } \\
\text { Tanaman } \\
(\mathrm{m})\end{array}$ & $\begin{array}{l}\text { Jumlah } \\
\text { Stolon }\end{array}$ & $\begin{array}{l}\text { Panjang } \\
\text { stolon } \\
(\mathrm{cm})\end{array}$ & $\begin{array}{l}\text { Jumlah Tunas } \\
\text { Langsung }\end{array}$ \\
\hline WKR- TP & 127 & 2,96 & 0 & 0 & 10,30 \\
WKR- IP & 102 & 0,66 & 2,3 & 36 & 0 \\
WFR- TP & 97,2 & 1,92 & 0 & 0 & 7,88 \\
WBR- TP & 151,6 & 2,83 & 0 & 0 & 10 \\
KDR- TP & 92,3 & 2,24 & 0 & 0 & 14 \\
KDR- IU & 128,3 & 0,63 & 3 & 22 & 0 \\
\hline
\end{tabular}

Tanaman tertinggi terdapat pada genotipe WKR-TP $(2,96 \mathrm{~m})$, diikuti oleh WBR-TP $(2,83 \mathrm{~m})$, KDR-TP $(2,24 \mathrm{~m})$ dan WFR-TP (1,92 m) Sebaliknya kedua talas genotipe lainnya memiliki tinggi lebih rendah, yaitu genotipe Ifen Putih ( $0,66 \mathrm{~m})$ dan Ifen Ungu $(0,63 \mathrm{~m})$.

Semua genotipe talas Mapia memiliki tunas langsung (sucker). Jumlah tunas terbanyak pada genotipe talas Mapia di Kampung Kpudori yaitu 14, sedangkan di Kampung Wakre dan Warbor rata-rata 10 tunas, dan Kampung Wafor 8 tunas. Jumlah stolon genotipe Ifen Putih rata-rata sebanyak 2 dan Ifen Ungu mempunyai rata-rata 3 stolon.

\section{Morfologi Daun}

Bentuk dasar pada genotipe talas Mapia di seluruh lokasi penelitian adalah sagitate, sedangkan genotipe talas lainnya yaitu Ifen Putih dan Ifen Ungu adalah hastate (Tabel 3). Terdapat 2 posisi permukaan dan bentuk tepi daun pada genotipe talas. Posisi permukaan daun tegak terdapat pada genotipe talas Mapia dan horisontal pada talas Ifen Putih dan Ifen Ungu. Bentuk tepi daun lurus (tidak bergelombang) terdapat pada genotipe talas Mapia dan tepi daun bergelombang terdapat pada talas Ifen Putih dan Ifen Ungu (Gambar 1).

Genotipe talas di Kabupaten Supiori memiliki warna daun yang didominasi oleh warna hijau, sedangkan warna daun hijau garis keputihan hanya terdapat pada genotipe talas Ifen Putih, sedangkan genotipe talas Ifen Ungu berwarnaa hijau dengan bercak ungu. Variasi warna daun tidak terdapat pada semua genotipe talas Mapia (Tabel 4).

Pada Tabel 5, karakter warna tepi daun, pola persimpangan tangkai daun dan warna persimpangan daun memiliki 3 karakter yang berbeda. Pada tepi daun terdapat warna hijau, keputihan dan ungu yang didominasi warna hijau. Untuk pola persimpangan terdapat 2 karakter yaitu kecil dan menengah. Sama halnya dengan warna tepi daun, warna persimpangan daun memiliki 3 karakter yang berbeda yaitu merah, kuning dan ungu dengan warna merah lebih dominan

Pada karakter warna tulang daun terdapat 3 perbedaan warna yaitu hijau, keputihan dan ungu. Untuk pola tulang daun terdapat 2 pola yaitu pola $\mathrm{Y}$ dan pola I, sedangkan warna tangkai daun terdapat 3 warna yaitu kuning, keputihan dan hijau terang. Warna kuning adalah warna dominan yang terdapat pada talas Mapia di semua Kampung (Tabel 6). 


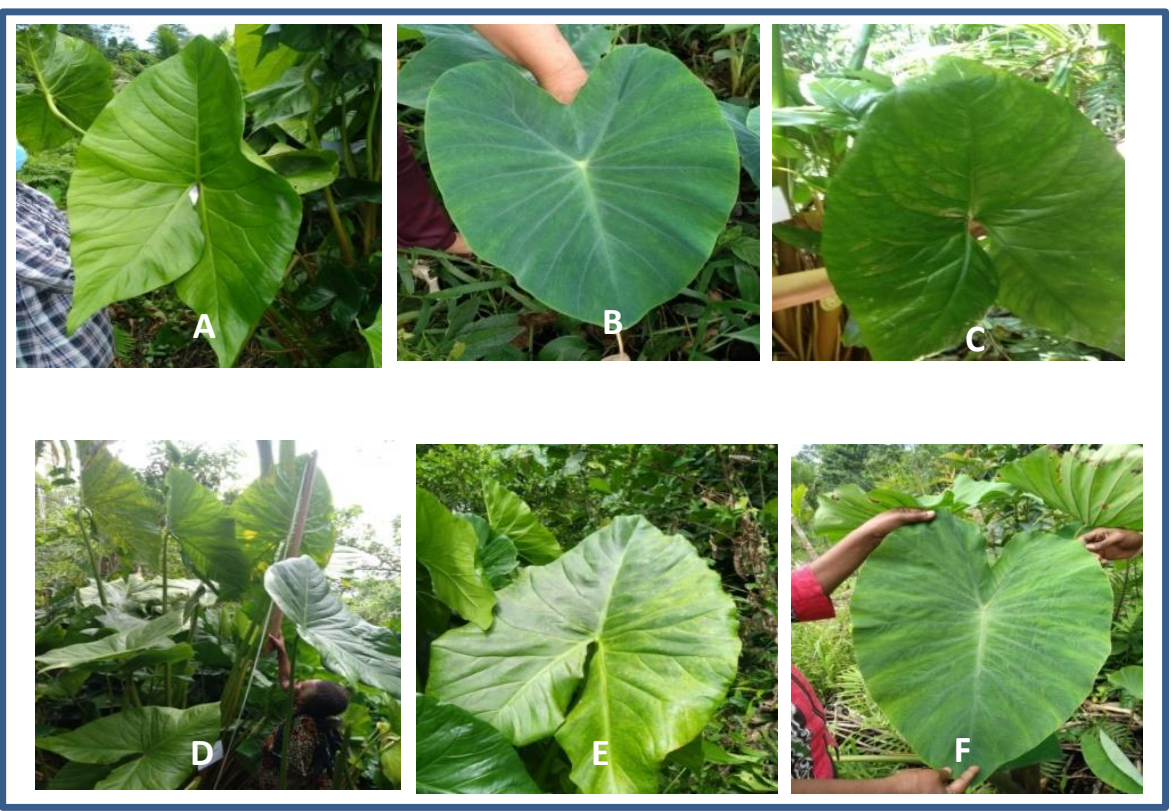

Gambar 1. Morfologi Daun Talas (A) Genotipe WKR-TP, (B)Genotipe WKR-IP, (C) Genotipe WFR-TP, (D) Genotipe WBR-TP, (E) Genotipe KDR-TP dan (F) Genotipe KDR-IU

Tabel 3. Karakter Bentuk Dasar Daun, Posisi Permukaan Daun dan Bentuk Tepi Daun Talas

\begin{tabular}{|c|c|c|c|}
\hline $\begin{array}{l}\text { Genotipe } \\
\text { Talas }\end{array}$ & Bentuk dasar daun & Posisi permukaan daun & Bentuk tepi daun \\
\hline WKR-TP & Sagitate (anak panah) & Tegak puncak & $\begin{array}{c}\text { Lurus (tidak } \\
\text { bergelombang) }\end{array}$ \\
\hline WKR-IP & Hastate (Jantung) & Horisontal & bergelombang \\
\hline WFR-TP & Sagitate (anak Panah) & Tegak puncak & $\begin{array}{c}\text { Lurus (tidak } \\
\text { bergelombang) }\end{array}$ \\
\hline WBR-TP & Sagitate (anak Panah) & Tegak puncak & $\begin{array}{c}\text { Lurus (tidak } \\
\text { bergelombang) }\end{array}$ \\
\hline KDR-TP & Sagitate (anak Panah) & Tegak puncak & $\begin{array}{c}\text { Lurus (tidak } \\
\text { bergelombang) }\end{array}$ \\
\hline KDR-IU & Hastate (Jantung) & Horisontal & bergelombang \\
\hline
\end{tabular}

Tabel 4. Karakter Warna Daun, Variasi Warna Daun dan Tipe Variasi Warna Daun Talas

\begin{tabular}{lccc}
\hline $\begin{array}{c}\text { Genotipe } \\
\text { Talas }\end{array}$ & Warna Daun & Variasi Warna Daun & $\begin{array}{c}\text { Tipe Variasi Warna } \\
\text { Daun }\end{array}$ \\
\hline WKR-TP & Hijau & Tidak ada & Tidak ada \\
WKR-IP & Hijau & Putih & Bergaris \\
WFR-TP & Hijau & Tidak ada & Tidak ada \\
WBR-TP & Hijau & Tidak ada & Tidak ada \\
KDR-TP & Hijau & Tidak ada & Tidak ada \\
KDR-IU & Hijau & Ungu & Bercak \\
\hline
\end{tabular}


Tabel 5. Karakter Warna Tepi Daun, Pola Persimpangan Tangkai Daun dan Warna Persimpangan Daun Talas

\begin{tabular}{lccc}
\hline $\begin{array}{c}\text { Genotipe } \\
\text { Talas }\end{array}$ & Warna Tepi Daun & $\begin{array}{c}\text { Pola Persimpangan } \\
\text { Tangkai Daun }\end{array}$ & $\begin{array}{c}\text { Warna Persimpangan } \\
\text { Daun }\end{array}$ \\
\hline WKR-TP & Hijau & Menengah & Merah \\
WKR-IP & Keputihan & Kecil & Kuning \\
WFR-TP & Hijau & Menengah & Merah \\
WBR-TP & Hijau & Menengah & Merah \\
KDR-TP & Hijau & Menengah & Merah \\
KDR-IU & ungu & Kecil & ungu \\
\hline
\end{tabular}

Tabel 6. Karakter Warna Tulang Daun Utama, Pola Tulang Daun dan Warna Tangkai Daun

\begin{tabular}{lclc}
\hline $\begin{array}{c}\text { Genotipe } \\
\text { Talas }\end{array}$ & $\begin{array}{c}\text { Warna Tulang Daun } \\
\text { Utama }\end{array}$ & Pola Tulang Daun & Warna Tangkai Daun \\
\hline WKR-TP & Hijau & Pola Y dan meluas & Kuning \\
WKR-IP & Keputihan & Pola Y dan meluas & Keputihan \\
WFR-TP & Hijau & Pola Y dan meluas & Kuning \\
WBR-TP & Hijau & Pola Y dan meluas & Kuning \\
KDR-TP & Hijau & Pola Y dan meluas & Kuning \\
KDR-IU & Ungu & Pola I & Hijau terang \\
\hline
\end{tabular}

Terdapat 3 perbedaan warna cincin dasar pada tangkai daun yaitu merah, putih dan ungu, sedangkan pada ketebalan lapisan lilin terdapat dua perbedaan yaitu mulai dari sedang hingga tinggi (Tabel 7).

Warna pelepah daun pada semua genotip talas berwarna hijau, kecuali genotipe Ifen Putih berwarna hijau muda dan genotipe Ifen Ungu berwarna hijau dengan sedikit bercak ungu (Tabel 7).

\section{Karakter Umbi}

Umbi adalah bagian tanaman talas yang paling banyak digunakan.Ukuran umbi terpanjang $(12,3 \mathrm{~cm})$ terdapat pada genotipe talas Mapia di Kampung Kpudori. Umbi talas yang diamati tidak memiliki cabang dengan bentuk beragam mulai dari bulat, memanjang, silinder, kerucut dan datar.

Bobot umbi tertinggi terdapat pada genotipe talas Mapia di kampung Warbor dengan bobot $2,21 \mathrm{~kg}$, sedangkan rata-rata bobot umbi genotipe talas Mapia di Kampung Wafor 2,17 kg, kam- pung Kpudori 1,86 kg dan kampung Wakre 1,6 kg. Genotipe talas Ifen Puith dan Ifen Ungu memiliki bobot lebih rendah dibandingkan genotipe talas Mapia (Tabel 8).

Warna daging umbi bagian luar dan warna daging umbi bagian dalam memiliki 3 karakter warna.Karakter permukaan kulit umbi memiliki 3 karakter juga yaitu berserat, berserat dan berserat dan lembut (Tabel 9).

\section{Analisis Tingkat Kemiripan}

Perhitungan tingkat kemiripan karakter morfologi talas dilakukan dengan menggunakan aplikasi SPSS versi 16. Tahapan dalam analisa tingkat kemiripan sebagai berikut : (1) Menentukan skor hasil pengamatan dari seluruh karakter yang diamati, (2) Memasukkan data skoring dalam aplikasi SPSS. Hasil pengukuran tingkat kemiripan diperoleh untuk mengetahui kekerabatan antar genotipe talas yang diteliti. Tingkat kemiripan antar genotipe talas di 
Kabupaten Supiori dapat dilihat pada Tabel 10 di bawah ini.

Berdasarkan Tabel 10, nilai koefisien asosiasi yang paling tinggi terdapat pada genotipe KDR-TP dan KDR-IU yaitu sebesar 11,044. Hal ini menunjukkan bahwa kedua genotipe tersebut memiliki tingkat kemiripan paling jauh dibandingkan dengan genotipe lainnya. Sedangkan nilai koefisien terendah terdapat pada genotipe WKR-TP dan WBR-TP dengan nilai koefisien 3,760 yang menunjukkan bahwa aksesi WKR-TP dan WFR-TP memiliki tingkat kemiripan yang tinggi. Hasil analisis koefisien korelasi selanjutnya digunakan untuk membuat dendogram (Gambar 3). Hasil pengelompokkan berdasarkan karakter morfologi talas pada dendo-gram menunjukkan terdapat 2 kelompok besar dari 6 genotipe yang diamati.

Tabel 7. Karakter Warna Cincin Dasar Tangkai, Warna Pelepah, Warna Tepi Pelepah dan Lapisan Lilin Pada Daun

\begin{tabular}{|c|c|c|c|c|}
\hline $\begin{array}{c}\text { Genotipe } \\
\text { Talas }\end{array}$ & $\begin{array}{l}\text { Warna Cincin } \\
\text { Dasar Tangkai }\end{array}$ & $\begin{array}{c}\text { Warna Pelepah } \\
\text { Daun }\end{array}$ & $\begin{array}{c}\text { Warna Tepi } \\
\text { Pelepah Daun }\end{array}$ & $\begin{array}{c}\text { Lapisan Lilin } \\
\text { Pada Daun }\end{array}$ \\
\hline WKR-TP & Merah & Hijau & Hijau & Sedang \\
\hline WKR-IP & Putih & Hijau muda & Hijau keabuan & Tinggi \\
\hline WFR-TP & Merah & Hijau & Hijau & Sedang \\
\hline WBR-TP & Merah & Hijau & Hijau & Sedang \\
\hline KDR-TP & Merah & Hijau & Hijau & Sedang \\
\hline KDR-IU & Ungu & Hijau bercak ungu & Hijau keunguan & Tinggi \\
\hline
\end{tabular}

Tabel 8. Karakter Umbi Talas

\begin{tabular}{lcccc}
\hline Jenis Talas & $\begin{array}{c}\text { Panjang } \\
\text { Umbi }(\mathrm{cm})\end{array}$ & Cabang Umbi & Bentuk Umbi & $\begin{array}{c}\text { Bobot Umbi } \\
(\mathrm{kg})\end{array}$ \\
\hline WKR-TP & 14,00 & Tidak bercabang & Bulat & 1,67 \\
WKR-IP & 17,3 & Tidak bercabang & Memanjang & 0,62 \\
WFR-TP & 16,00 & Tidak bercabang & Silinder & 2,17 \\
WBR-TP & 15,6 & Tidak bercabang & Kerucut & 2,21 \\
KDR-TP & 19,3 & Tidak bercabang & Datar dan & 1,86 \\
KDR-IU & 9,00 & Tidak bercabang & Memanjang & 0,53 \\
\hline
\end{tabular}

Tabel 9. Warna Daging Umbi Bagian Luar, Warna Daging Umbi Bagian Dalam dan Permukaan Kulit Umbi Talas

\begin{tabular}{lccc}
\hline $\begin{array}{c}\text { Genotipe } \\
\text { Talas }\end{array}$ & $\begin{array}{c}\text { Warna Daging } \\
\text { Umbi Bagian Luar }\end{array}$ & $\begin{array}{c}\text { Warna Daging Umbi } \\
\text { Bagian Dalam }\end{array}$ & Permukaan Kulit Umbi \\
\hline WKR-TP & Kuning & Kuning terang & Berserat \\
WKR-IP & Merah muda & Merah muda & Berserat dan bersisik \\
WFR-TP & Kuning & Kuning terang & Berserat \\
WBR-TP & Kuning & Kuning terang & Berserat \\
KDR-TP & Kuning & Kuning terang & Berserat \\
KDR-IU & Putih & Putih & Lembut \\
\hline
\end{tabular}


Tabel 10. Nilai Kemiripan 6 Genotipe Talas

\begin{tabular}{lcccccc}
\hline \multirow{2}{*}{ Case } & \multicolumn{5}{c}{ Euclidean Distance } \\
\cline { 2 - 7 } & WKR TP & WKRI IP & WFR TP & WBR TP & KDR TP & KDR IU \\
\hline WKR TP & 0,00 & 7,420 & 4,064 & 3,760 & 4,690 & 10,713 \\
WKR IP & & 0,00 & 7,805 & 7,172 & 7,355 & 6,354 \\
WFR TP & & & 0,00 & 4,207 & 4,538 & 11,003 \\
WBR TP & & & & 0,00 & 3,949 & 10,671 \\
KDR TP & & & & & 0,00 & 11,044 \\
KDR IU & & & & & & 0,00 \\
\hline
\end{tabular}

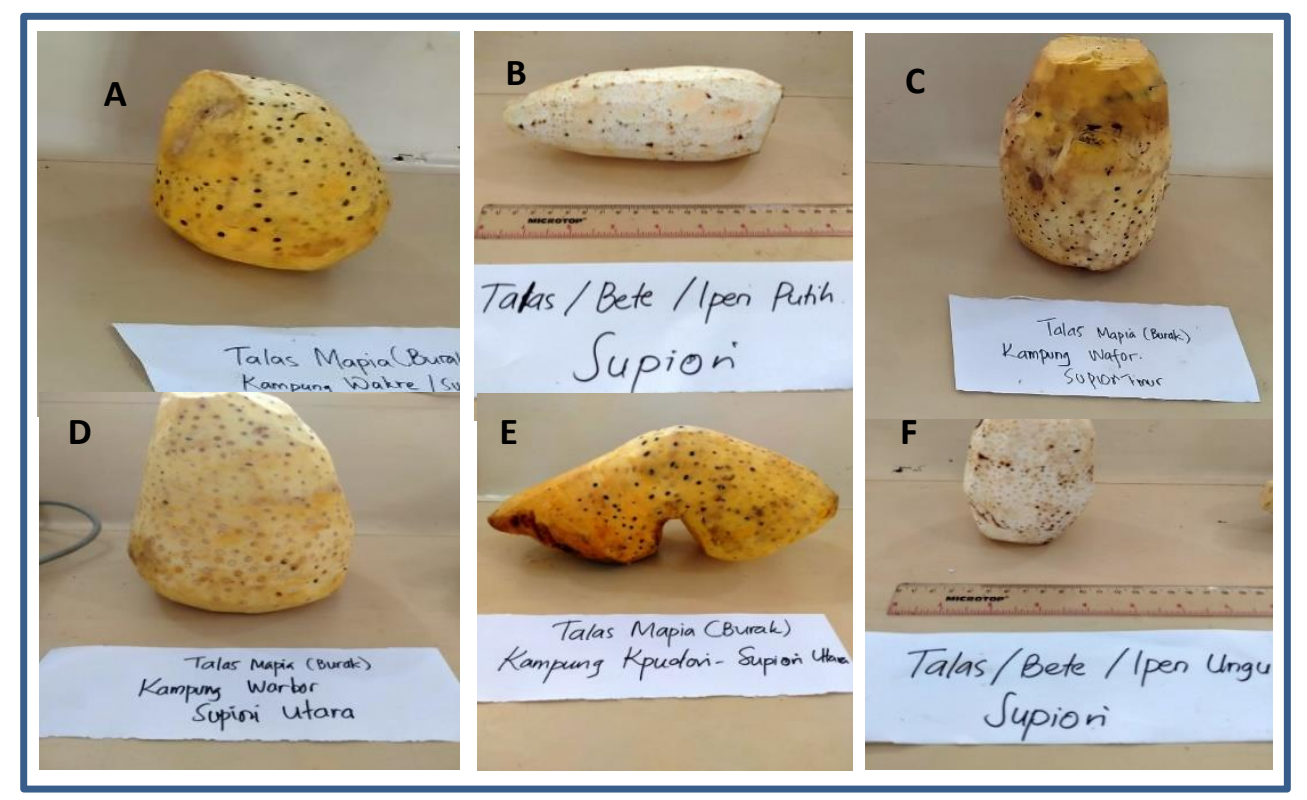

Gambar 2. Umbi Talas, (A) Genotipe WKR-TP, (B) Genotipe WKR-IP, (C) Genotipe WFR-TP, (D) Genotipe WBR-TP, (E) Genotipe KDR-TP, (F) Genotipe KDR-IU

Rescaled Distance Cluster Combine

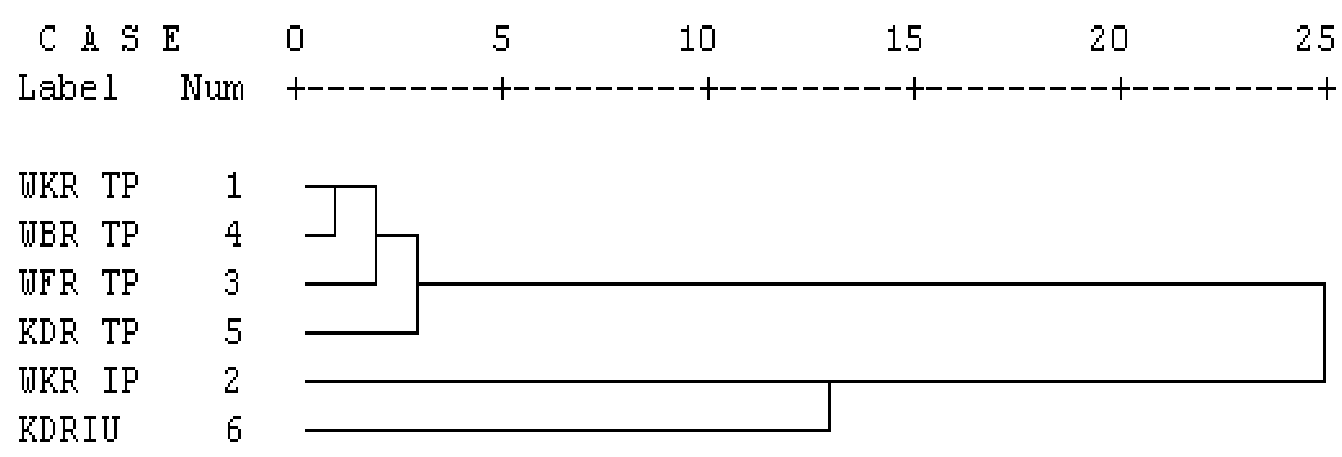

Gambar 3. Dendogram Hasil Analisis Kelompok 6 Genotipe Talas 
Berdasarkan dendogram di atas, terdapat 2 kelompok besar. Kelompok A beranggota WKR-TP, WBR-TP, WFRTP dan KDR-TP yang merupakan genotipe-genotipe talas Mapia dari kampung Wakre, Warbor, Warfor dan Kpudori sedangkan kelompok B beranggotakan WKR-IP dan KDR-IU yang merupakan genotipe talas dengan karakter-karakter morfologi yang berbeda dengan genotipe-genotipe talas Mapia. Ciri yang membedakan kelompok A dan B adalah posisi permukaan daun, warna daun, warna tepi daun, pola persimpangan tangkai daun, warna persimpangan daun, warna cincin dasar tangkai, warna pelepah daun, warna trpi pelepah daun, warna tulang daun utama, warna tangkai daun bentuk umbi, warna tunas, warna daging umbi bagian luar, warna daging umbi bagian dalam. Kelompok A kemudian memisah menjadi 2 sub kelompok a1 dan a2. Pemisahan kelompok-kelompok ini akibat adanya berbedaan pada ciri morfologi pada setiap genotipe talas yang diamati, yaitu umur panen, bobot umbi, panjang umbi, bentuk umbi, warna daun bunga, bentuk daun bunga, rentang tanaman, jumlah stolon dan tinggi tanaman. Genotipe talas yang terdapat dalam satu kelompok yang sama menandakan bahwa antar genotype.

\section{Kandungan Nutrisi Talas}

Hasil analisis kimia menunjukkan bahwa kadar air tertinggi terdapat pada genotipe talas Ifen Putih $(87,36 \%)$, diikuti oleh Ifen Ungu (86,05\%) sedangkan ke empat genotipe talas Mapia lainnya memiliki kadar air berkisar $83,03 \%-84,08 \%$.

Kadar abu tertinggi terdapat pada genotipe talas KDR-IU $(4,88 \%)$, diikuti oleh genotipe WFR-TP $(4,59 \%)$ dan asal KDR-TP (4,00\%). Kadar pati tertinggi terdapat pada genotipe WKR-IP $(67,24$ $\%)$, diikuti oleh genotipe WBR-TP $(6,21$ $\%)$, dan WFR-TP (65,06 \%). Kadar gula tertinggi terdapat pada genotipe KDR-IU $(11,01 \%)$ dan KDR-TP $(10,26 \%)$. Genotipe WKR-TP mengandung kadar amilosa tertinggi $(23,48 \%)$, diikuti oleh WBR-TP $(22,91 \%)$, Kadar Lemak tertinggi genotipe $\mathrm{KDR}-\mathrm{IU}(0,66 \%)$, diikuti oleh genotipe KDR-TP $(0,61 \%)$. Kadar protein tertinggi diperlihatkan oleh genotipe WFR-TP (8,81 \%), sedangkan genotipe talas Mapia lainnya berkisar dari $0,91 \%$ - 2,69\% dan genotipe Ifen Putih 3,33\% (Tabel 11).

Analisis kadar abu bertujuan untuk mengetahui kandungan mineral yang ada pada bahan yang diuji, menentukan baik tidaknya suatu proses pengolahan, mengetahui jenis bahan yang digunakan, memperkirakan kandungan bahan utama yang digunakan dalam pembuatan suatu produk, kadar abu juga digunakan sebagai parameter nilai gizi bahan makanan (Sudarmadji et al, 2010).

Tabel 11. Kadar Abu, Kadar Lemak dan Kadar Protein Umbi Talas Di Kabupaten Supiori

\begin{tabular}{lccccccc}
\hline $\begin{array}{c}\text { Genotipe } \\
\text { Talas }\end{array}$ & $\begin{array}{c}\text { Kadar } \\
\text { Air }(\% \\
\text { bb })\end{array}$ & $\begin{array}{c}\text { Kadar } \\
\text { Abu }(\% \\
\text { bk })\end{array}$ & $\begin{array}{c}\text { Kadar } \\
\text { Pati } \\
(\% \text { bk })\end{array}$ & $\begin{array}{c}\text { Kadar } \\
\text { Gula } \\
(\% \text { bk })\end{array}$ & $\begin{array}{c}\text { Kadar } \\
\text { Amilosa } \\
(\% \text { bk })\end{array}$ & $\begin{array}{c}\text { Kadar } \\
\text { Lemak } \\
(\% \text { bk })\end{array}$ & $\begin{array}{c}\text { Kadar } \\
\text { Protein }(\% \\
\text { bk })\end{array}$ \\
\hline WKR-TP & 84,08 & 2,61 & 53,33 & 6,16 & 23,48 & 0,33 & 0,91 \\
WKR-IP & 87,36 & 2,71 & 67,24 & 4,24 & 19,71 & 0,41 & 3,33 \\
WFR-TP & 83,14 & 4,59 & 65,06 & 3,08 & 19,51 & 0,28 & 8,81 \\
WBR-TP & 87,88 & 2,67 & 66,21 & 6,23 & 22,91 & 0,34 & 1,30 \\
KDR-TP & 83,03 & 4,00 & 61,94 & 10,26 & 17,39 & 0,61 & 2,69 \\
KDR- IU & 86,05 & 4,88 & 53,38 & 11,01 & 11,43 & 0,64 & 1,93 \\
\hline
\end{tabular}


Kadar abu adalah zat organik sisa suatu pembakaran zat organik dalam bahan pangan yang menunjukan kandungan mineral yang terdapat dalam suatu produk pangan (Ghozalli 2015). Abu total yang terkandung dalam produk pangan sangat dibatasi jumlahnya, dan kandungan abu total bersifat kritis (Feringo, 2019). Menurut Natalia (2010), bahwa umumnya jumlah mineral dalam produk pangan tidak lebih dari $4 \%$ dari total berat makanan. Kadar abu dapat mempengaruhi proses aktivitas fermentasi, kekuatan adonan, gizi, warna dan produk akhir (Kusumasari, et al., 2019).

Lemak merupakan bagian integral dari hampir semua bahan pangan. Beberapa jenis lemak yang digunakan dalam penyiapan makanan berasal dari hewan sedang lainnya dari tumbuhan. Lemak merupakan zat makanan yang penting untuk menjaga kesehatan tubuh manusia. Selain itu juga merupakan sumber energi yang lebih efektif dibanding dengan karbohidrat dan protein.Lemak terdapat pada hampir semua bahan pangan dengan kandungan yang berbeda-beda (Winarno, 2002). Lemak diartikan sebagai semua bahan organik yang dapat larut dalam pelarutpelarut organik yang memiliki kecenderungan nonpolar. Ke-lompok lipida ini secara khusus berbeda dengan karbohidrat dan protein yang tak larut dalam pelarut-pelarut organik (Sudarmadji et al., 2003). Winarno (2002) menyatakan bahwa lemak merupakan sumber energi yang lebih besar dibandingkan dengan protein dan karbohidrat karena satu gram minyak atau lemak dapat menghasilkan energi sebesar 9 kkal, sedangkan protein dan karbohidrat hanya menghasilkan $4 \mathrm{kkal}$.

Lemak dapat mengalami kerusakan akibat adanya panas yang menyebabkan kadar lemaknya berkurang (Muchtadi, 1989). Semakin kecil kadar lemak pada bahan tepung semakin baik. Kandungan lemak yang rendah meminimalisir ketengikan (Kusumasari, et al., 2019). Ketengikan terjadi bila komponen cita rasa dan bau mudah menguap sebagai akibat dari kerusakan oksidatif pada lemak (Raharjo, 2004, Muttakin et al., 2015). Selain itu menurut Muchtadi (1989), komponen gizi lemak berubah disebabkan oleh pecahnya komponenkomponen lemak menjadi produk volatil, seperti aldehid, keton, alkohol, asam-asam dan hidro-karbon, yang sangat berpengaruh terha-dap pembentukan flavor.

Protein merupakan senyawa organik penting bagi tubuh yang berfungsi sebagai zat pengatur dan zat pembangun (Sakti et al.,2016). Umbi-umbian bukan merupakan pangan sumber protein, karena kandungan proteinnya rendah. Rata-rata kadar protein tepung umbiumbian lokal ini lebih rendah dibanding tepung terigu $(13,5 \%)$. Umbi-umbian juga tidak mengandung jenis protein gliadin dan glutenin (Rufaidah, 2000) yang membentuk gluten pada tepung terigu, sehingga tepung umbi - umbian lokal potensial sebagai bahan baku produk yang tidak memerlukan proses pengembangan (Pattikawa et al., 2012).

Dalam sintesisnya, protein terbentuk dari unsur-unsur hara seperti $\mathrm{C}$, $\mathrm{H}, \mathrm{O}, \mathrm{N}, \mathrm{S}, \mathrm{P}$, dan $\mathrm{K}$ dan berperan dalam aktivitas sel sehari-hari seperti proses pembelahan maupun menggantikan sel yang sudah rusak atau tua serta proses metabolisme lainnya (Parman, 2007).

\section{KESIMPULAN}

Hasil analisis klaster menunjukkan adanya 2 kelompok besar dari 6 genotipe talas yang diamati. Kelompok A (WKR-TP, WBR-TP, WFR-TP dan KDR-TP) merupakan genotipe-genotipe talas Mapia dari kampung Wakre, Warbor, Warfor dan Kpudori sedangkan 
kelompok B (WKR-IP dan KDR-IU) merupakan genotipe talas dengan karakter-karakter morfologi yang berbeda dengan genotipe-genotipe talas Mapia. Perbedan tersebut dicirikan oleh perbedaan karakter posisi permukaan daun, warna daun, warna tepi daun, warna persimpangan daun, warna cincin dasar tangkai, warna pelepah daun, warna tulang daun utama, warna tangkai Hasil analisis kadar nutrisi (kandungan air, abu, pati, gula, amilosa, lemak dan protein) bervariasi antar 6 genotipe talas.

Kadar nutrisi tertinggi antara lain kadar air $(87,88 \%)$ pada genotipe WBRTP, kadar abu $(4,59 \%)$ pada genotipe WFR-TP, kadar pati $(67,24 \%)$ pada genotipe WKR-IP, kadar gula $(11,01 \%)$ pada KFR-IU, kadar amilosa $(22,91 \%)$ pada WBR-TP, kadar lemak $(0,64 \%)$ pada KDR-IU, kadar protein $(8,81 \%)$ pada WFR-TP.

\section{UCAPAN TERIMA KASIH}

Terima kasih kepada kepala kampung, tokoh adat, tokoh agama, tokoh masyarakat, Kelompok Tani Wanita (KWT), Penyuluh Pertanian di Distrik Supiori Utara dan Timur yang telah mendukung dalam pelaksanaan penelitian.

\section{DAFTAR PUSTAKA}

Feringo, T. (2019). Analisis Kadar Abu, Kadar Abu Tak Larut Asam dan Kadar Lemak Pada Makanan Ringan di Balai Riset dan Standarisasi Industri Medan. Tugas Akhir. Fakultas Farmasi Universitas Sumatera Utara.

Ghozalli, M. 2015. Karateristik Tepung Kedelai dari Jenis Impor dan Lokal (Varietas Anjasmoro dan Baluran) Dengan Perlakuan Perebusan dan Tanpa Perebusan.Skripsi. Universitas Jember.

Goncalves, R.F., A.M.S. Silva, P. Valentao, F. Ferreres, A. GilIzquierdo, J.B. Silva, D. Santos, and P.B. Andrade. 2013. Influence of Taro (Colocasia esculenta L.Shott) Growth Conditions On The Phenolic Composition and Biological Properties. Elseiver : Food Chemistry 14 (1) : 34803485.

Kusumasari, S., Eris, F.R., Mulyati, S., dan Pamela, V.Y. 2019. Karakterisasi Sifat Fisikokimia Tepung Talas Beneng Sebagai Pangan Khas Kabupaten Pandeglang. Jurnal Agroekotek 11 (2) :227-234

Minantyorini dan Hanarida. 2002. Panduan Karakterisasi dan Evaluasi Plasma Nutfah Talas (Colocasia esculentaL. Shott). Departemen Pertanian.

Muchtadi, D. 1989. Petunjuk Laboratorium Evaluasi Nilai Gizi Pangan. Depdikbud PAU Pangan dan Gizi IPB. Bogor.

Muttakin, S., Muharfiza, Lestari, S. 2015. Reduksi Kadar Oksalat pada Talas Lokal Banten Melalui Perendaman dalam Air Garam.Prosiding Seminar Nasional Masyarakat Biodiversitas Indonesia1 :17071710.

Natalia D. 2010. Sifat Fisikokimia dan Indeks Glikemik Berbagai Produk Snack. Skripsi. Institut Pertanian Bogor.

Parman, S. 2007. Kandungan Protein dan Abu Tanaman Alfafa (Medicago sativa L.) Setelah Pemupukan Biorisa. Jurnal Bioma 9 (2) :38-44.

Pattikawa, A.B., Suparno, A dan Prabawardhani, S. 2012. Analisis nutrisi umbi ubi jalar (Ipomoea batatas (L.) Lamb.) Untuk Konsumsi Bayi dan Anak-Anak Suku Dani di Distrik Kurulu Kabupaten Jayawijaya. Cassowary, 1(1), 4754.Doi: 
https://doi.org/10.30862/casssowa ry.cs.v1.i1.4

Raharjo, S. 2004. Kerusakan Oksidatif pada Makanan.Pusat Studi Pangan dan Gizi UGM.Yogyakarta.

Rufaidah, V.W. 2000. Evaluation of Ganyong Starch Capability As Tapioca Starch Subtitute On Fish Nugget. Prosiding Seminar Nasional Industri Pangan, Surabaya.

Sakti H., Lestari S., dan Supriadi A. 2016. Perubahan Mutu Ikan Gabus (Channa striata) Asap Selama Penyimpanan. Jurnal Teknologi Hasil Perikanan. 5(1): 11-18.

Singh D and T Okpul (2000) Evaluation of 12 taro (Colocasia esculenta (L.) Schott) leaf blight resistant lines for yield and eating quality in Papua New Guinea. SABRAO,
J,Breeding \& Genetics. 32(1), 3945.

Sudarmadji, S., Haryono, B., dan Suhardi. (2003). Analisa Bahan Makanan dan Pertanian. Kanisius. Yogyakarta.

Sudarmadji, S., Haryono, B., dan Suhardi. (2010). Analisa Bahan Makanan dan Pertanian. Liberty Yogyakarta.

Winarno, F.G. 2002.Kimia Pangan dan Gizi. Gramedia Pustaka Utama. Jakarta.

Yalu, A. Singh, D., \& Yadav, S. (2009). Taro Improvement and development in Papua New Guinea - A success story. Asia Pacific Association of Agricultural Research Institutions (APAARI) Publications 